\title{
Effect of Dietary Supplementation with Fenugreek, Marjoram and Their Combination on Performance and Carcass Traits of NZW Growing Rabbits Tag El-Din, T.H. ${ }^{\text {; F. S. A. Ismail }}{ }^{2}$; M. R. EL-Gogary ${ }^{2}$ and M. H. Abd El-Hamed ${ }^{2}$ ${ }^{1}$ Department of Poultry Production, Faculty of Agriculture, Damietta University, Egypt ${ }^{2}$ Department of Poultry Production, Faculty of Agriculture, Al-Mansourah University, Egypt
}

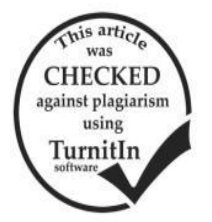

\begin{abstract}
A study was conducted to investigate the effect of two dietary herbal plants (fenugreek seeds $(\mathrm{F})$, marjoram leaves (M) and their combination $(\mathrm{F}+\mathrm{M})$ ) supplementation on productive performance and carcass traits of New Zealand White rabbits (NZW). The herbal plants were dietary added for 8 weeks at the following levels: T1 (0\% F+0\% M), T2 $(0.25 \% \mathrm{~F}), \mathrm{T} 3(0$. $25 \% \mathrm{M}), \mathrm{T} 4(0.50 \% \mathrm{~F}), \mathrm{T} 5(0.50 \% \mathrm{M}), \mathrm{T} 6(0.25 \% \mathrm{~F}+0.25 \% \mathrm{M}), \mathrm{T} 7(0.50 \% \mathrm{~F}+0.25 \% \mathrm{M}), \mathrm{T} 8(0.25 \% \mathrm{~F}+0.50 \% \mathrm{M})$ and T9 $(0.50 \%$ $\mathrm{F}+0.50 \% \mathrm{M})$. Ninety unsexed rabbits at 6 week of age (750-775g initial body weight) were divided into 9 treatment groups. Each treatment had 10 rabbits. At the end of the feeding traits, no significant differences were observed in LBW of rabbits comparing with the control group. However, group 4 which fed fenugreek $(0.50 \%)$ achieved the highest final LBW at 14 weeks of age. During the whole period, means of feed consumption of rabbits were not significantly different among experimental groups. Concerning feed conversion ratio (FCR) for the whole experimental period, there were no significant differences among all groups. Herbal plants supplementation had no significant effect on relative weights of carcass yield, liver or heart. Generally, the present study concluded that the consumption of fenugreek and marjoram had positive effects on rabbit's performance and carcass traits of growing NZW rabbits.
\end{abstract}

Keywords: Rabbit, herbal plants, fenugreek, marjoram, production, carcass yield.

\section{INTRODUCTION}

Feed additives are a group of nutrient and nonnutrient compounds which helps in improving the efficiency of feed utilization and thus reducing the high cost of food. In the past, antibiotics were the most routinely used feed additives. Nowadays, use of antibiotics has been banned in many countries due to their alteration of gut microbiota and drug resistance of bacteria in humans. The global trend to go back to nature had enforced to use fenugreek seeds and marjoram leaves as natural growth promoters. Fenugreek has been used as a spice and a native medicine for many years. It has possessed antibacterial, antifungal, antiviral, and antioxidant activities. Fenugreek seeds are rich in protein, fat, total carbohydrates and minerals such as calcium, phosphorus, iron, zinc and magnesium (Gupta et al, 1996), and contains active constituents such as alkaloids, flavonoids, steroids, saponins and phenolic (kor and Zadeh 2013) which help to enhance antioxidant capacity (Srinivasan, 2006). Fenugreek seeds in the diet significantly improve the body weight of broiler chicken (Yatoo et al., 2012 and Qureshi et al., 2015). In addition, Zeweil et al. (2015) observed that feed additives fenugreek at $0.6 \%$ to rabbit diets significantly improved final body weight, body weight gain, feed intake, feed conversion ratio and performance index as compared to the control group. While Feeding diet supplemented with $0.3 \%$ fenugreek significantly increased dressing $\%$ and the absolute and relative weight of spleen, kidneys, liver, heart and lungs of Californian rabbits (Seleem, 2008). Oregano leaves (Origanum vulgare L.) essential oil is one of many plant extracts that are used at present as supplements in animal's diets. It contains mainly carvacrol, thymol and their precursors (terpinene and p-cypene) and it possesses intense in vitro antimicrobial (Dorman and Deans, 2000), antifungal (Daouk et al., 1995) and antioxidant (Cervato et al., 2000) properties, making it an appropriate candidate as a replacement for antibiotic growth promoters and also a promising food additive in order to prevent meat lipid oxidation. Oregano aids nutrient digestion and absorption, it displays antibacterial properties and prevents gut misbalances (De Koning et al., 1993). Untea et al. (2011) considered that oregano stabilizes the gut microflora and increases nutrient digestibility. Amount of volatile oil from the Origanum vulgare $L$ is varying from $0.18-0.45 \%$ and $0.32-1.02 \%$ in fresh and dried plant (Robu and Milica, 2004). The present study was carried out to evaluate the beneficial effect of fenugreek seeds and marjoram leaves alone at two levels $(0.25$ and $0.50 \%)$ and in combination at different levels on performance and carcass traits of NZW rabbits.

\section{MATERIALS AND METHODS}

Experiments of the present study were carried out at the Rabbits Farm of Abo- Greada at Damietta Governorate that follows Faculty of Agriculture, Damietta University.

\section{Experimental Design}

Ninety unsexed NZW rabbits at 6 weeks of age were divided into 9 treatment groups, each treatment had 10 rabbits. The mean average weight of rabbits in all groups ranged from 750 to $775 \mathrm{~g}$.

Experimental diets:

Nine diets were made from different local materials. All diets were formulated to meet all the essential nutrient requirements of growing rabbits (De Blas and Mateots, 1998). The ingredients and chemical composition of experimental diets are shown in Table 1. All the diets were pelleted (3.5 mm diameter). Feed and fresh water were offered ad libitum to the experimental groups.

\section{Animal housing:}

All rabbit were housed individually in galvanized wire cages provided with feeders and automatic nipple 
drinkers. Cages were kept in an open side well ventilated pen.

\section{Growth trail:}

A comparative feeding experiment was carried out to the study the effects of adding fenugreek seeds and/or marjoram leaves at different levels to the rabbit's diets on growth performance and carcass traits. Feed consumption was recorded weekly during the 8- week experimental period. Rabbits were individually weighed each week from weaning (at 6 week of age) to slaughter (at 14 week of age) to obtain live body weight and body weight gain.

\section{Slaughter test}

At the end of the feeding trial $\left(14^{\text {th }}\right.$ week of age), three rabbits from each group were selected for slaughter test. Just prior to slaughter and again after complete bleeding, the rabbits were individually weighed, and their fur and legs were plucked and then eviscerated. Records on individual weights of eviscerated carcass and giblets (including heart, liver and kidney) were done. Carcass yield was calculated as eviscerated carcass plus giblets. All carcass traits were expressed as $\%$ of live body weight at slaughter.

Table 1: Ingredients and chemical analysis $(\%)$ of the experimental pelleted rations

\begin{tabular}{|c|c|c|c|c|c|c|c|c|c|}
\hline \multirow{2}{*}{ Items } & \multicolumn{9}{|c|}{ Experimental diets } \\
\hline & T1 & $\mathbf{T} 2$ & T3 & T4 & T5 & T6 & T7 & T8 & T9 \\
\hline \multicolumn{10}{|l|}{ Ingredients \%: } \\
\hline Clover hay & 38.4 & 38.15 & 38.15 & 37.9 & 37.9 & 37.9 & 37.65 & 37.65 & 37.4 \\
\hline Yellow maize & 10.1 & 10.1 & 10.1 & 10.1 & 10.1 & 10.1 & 10.1 & 10.1 & 10.1 \\
\hline Wheat bran & 32.4 & 32.4 & 32.4 & 32.4 & 32.4 & 32.4 & 32.4 & 32.4 & 32.4 \\
\hline Soybean meal & 13.8 & 13.8 & 13.8 & 13.8 & 13.8 & 13.8 & 13.8 & 13.8 & 13.8 \\
\hline Molasses & 4.0 & 4.0 & 4.0 & 4.0 & 4.0 & 4.0 & 4.0 & 4.0 & 4.0 \\
\hline Salt & 0.3 & 0.3 & 0.3 & 0.3 & 0.3 & 0.3 & 0.3 & 0.3 & 0.3 \\
\hline Vitamins \& Minerals permix* & 0.4 & 0.4 & 0.4 & 0.4 & 0.4 & 0.4 & 0.4 & 0.4 & 0.4 \\
\hline DL-Methionine & 0.3 & 0.3 & 0.3 & 0.3 & 0.3 & 0.3 & 0.3 & 0.3 & 0.3 \\
\hline DL .Lysine & 0.1 & 0.1 & 0.1 & 0.1 & 0.1 & 0.1 & 0.1 & 0.1 & 0.1 \\
\hline Cholin Chlorid & 0.1 & 0.1 & 0.1 & 0.1 & 0.1 & 0.1 & 0.1 & 0.1 & 0.1 \\
\hline Anticoccidia & 0.1 & 0.1 & 0.1 & 0.1 & 0.1 & 0.1 & 0.1 & 0.1 & 0.1 \\
\hline Fenugreek & - & 0.25 & - & 0.50 & - & 0.25 & 0.50 & 0.25 & 0.50 \\
\hline Marjoram & - & - & 0.25 & - & 0.50 & 0.25 & 0.25 & 0.50 & 0.50 \\
\hline Total & 100 & 100 & 100 & 100 & 100 & 100 & 100 & 100 & 100 \\
\hline Chemical analysis (as fed): & 89.05 & 89.14 & 90.12 & 90.45 & 90.83 & 89.62 & 89.50 & 89.87 & 86.45 \\
\hline $\mathrm{DM} \%$ & 81.28 & 81.5 & 82.54 & 82.48 & 84.23 & 81.81 & 83.12 & 81.93 & 78.77 \\
\hline $\mathrm{OM} \%$ & 17.21 & 17.90 & 17.16 & 17.22 & 17.16 & 17.19 & 17.22 & 17.19 & 17.22 \\
\hline $\mathrm{CP} \%$ & 11.21 & 9.37 & 11.69 & 12.26 & 10.90 & 10.56 & 11.26 & 9.72 & 11.43 \\
\hline F\% & 1.50 & 1.07 & 2.97 & 2.34 & 1.33 & 1.83 & 1.97 & 2.03 & 1.13 \\
\hline $\begin{array}{l}\text { EE\% } \\
\text { NFE\% }\end{array}$ & 50.97 & 53.16 & 50.72 & 50.57 & 54.84 & 52.23 & 52.67 & 52.99 & 48.99 \\
\hline $\mathrm{DE}(\mathrm{Kcal} / \mathrm{kg})$ & 2877 & 2830 & 3031 & 2904 & 3062 & 2850 & 2924 & 2893 & 2820 \\
\hline
\end{tabular}

* Each kilogram contains: Vit A 2000000 IU, Vit. $D_{3} 150000$ IU, Vit. E 8.33g, Vit. K 0.33g, Vit. B 1 0.33g, Vit. B B $_{2}$.0g, Vit. B 6 0.33g, Vit. $B_{12} 1.7 \mathrm{mg}$, Vit. $B_{5}$ 8.33g, Pantothenic acid 3.33g, Zn 11.7g, Fe 12.5, Cu 0.5g, Co 1.33 mg, Se 16.6

\section{Statistical analysis:}

Statistical analysis for the obtained data was performed by analysis of variance using the method of least square analysis of Co-variance (SAS, 1996). Duncan's multiple range tests was used to separate significant differences among means (Duncan, 1955).

\section{RESULTS AND DISCUSSION}

Table 2 shows the effect of different levels of fenugreek $(\mathrm{F})$, marjoram $(\mathrm{M})$ and their combination $(\mathrm{F}+\mathrm{M})$ on LBW of rabbits during the whole experimental period (6-14 week of age). No significant differences were observed in LBW of rabbits throughout the whole experimental period between each treatment and the control. However, group 4 which fed fenugreek $(0.50 \%)$ achieved the highest final LBW at $14^{\text {th }}$ week of age. Means of final LBW at $14^{\text {th }}$ week of age were 2.501, 2.492,2.442, 2.522, 2.371, 2.464, 2.487, 2.464 and $2.477 \mathrm{~kg}$ for rabbit's groups fed $\mathrm{T} 1(0 \%$ $\mathrm{F}+0 \% \mathrm{M}), \mathrm{T} 2(0.25 \% \mathrm{~F}), \mathrm{T} 3(0.25 \% \mathrm{M}), \mathrm{T} 4(0.50 \% \mathrm{~F})$, T5 $(0.50 \% \mathrm{M}), \mathrm{T} 6(0.25 \% \mathrm{~F}+0.25 \% \mathrm{M}), \mathrm{T} 7(0.50 \% \mathrm{~F}$ $+0.25 \% \mathrm{M}), \mathrm{T} 8(0.25 \% \mathrm{~F}+0.50 \% \mathrm{M})$ and $\mathrm{T} 9$ $(0.50 \% \mathrm{~F}+0.50 \% \mathrm{M})$, respectively. These results are in agreement with the findings of Abdelatif et al. (2012) who found slight gradual increase in LBW of rabbits supplemented with fenugreek. Similarly, other researchers such as Zeweil et al. (2015) indicated that different supplementation of fenugreek powder to growing rabbit's diets improved the performance of the experimental rabbits compared to un-supplemented group. Also, the results are in agreement with findings of Rayes et al. (2009) who mentioned that improvement of body weight gain of rabbits fed fenugreek diets might be attributed to increase in feed intake or to the fenugreek contents of active compounds such as antibacterial, antifungal, anti-inflammatory, carminative and antioxidant activities. Also, Hernandez et al. (2004) found that the improvement due to fenugreek diets might be due to presence of the fatty acids or due to stimulating effect on the digestive system. In addition, Botsoglou et al. (2004) observed that dietary inclusion of 100 and $200 \mathrm{mg} / \mathrm{kg}$ diet with an essential oil from oregano (marjoram) exerted no growth promoting effect in rabbits. However, Ibrahim et al. (2000) found that dietary supplementation with $0.5 \%$ oregano extract significantly increased LBW compared to a control group. 
Table 2: Effect of dietary supplementation with fenugreek, marjoram, and their combination on live body weight of rabbits from $6^{\text {th }}$ to $14^{\text {th }}$ week of age.

\begin{tabular}{|c|c|c|c|c|c|c|c|c|c|}
\hline Age (wk) & $6^{\text {th }}$ & $7^{\text {th }}$ & $8^{\text {th }}$ & $9^{\text {th }}$ & $10^{\text {th }}$ & $11^{\text {th }}$ & $12^{\text {th }}$ & $13^{\text {th }}$ & $14^{\text {th }}$ \\
\hline Treatments & $X \pm S E$ & $X \pm S E$ & $X \pm S E$ & $X \pm S E$ & $X \pm S E$ & $X \pm S E$ & $X \pm S E$ & $X \pm S E$ & $X \pm S E$ \\
\hline $\mathrm{T}_{1}$ (Control) & $845.5 \pm 36.2$ & $1117.5 \pm 26.1$ & $1415.5 \pm 39.5$ & $1693.0 \pm 36.8$ & $1822.0 \pm 38.8$ & $2015.0 \pm 57.9$ & $2208.5 \pm 80.2$ & $2372.0 \pm 85.5$ & $2501.5 \pm 83.5$ \\
\hline $\mathrm{T}_{2} \quad(0.25 \% \mathrm{~F})$ & $845.5 \pm 29.6$ & $1104.5 \pm 21.5$ & $1362.5 \pm 32.6$ & $1579.5 \pm 31.5$ & $1788.5 \pm 30.0$ & $1985.0 \pm 31.7$ & $2200.0 \pm 39.3$ & $2380.5 \pm 46.8$ & $2492.0 \pm 45.2$ \\
\hline $\mathrm{T}_{3}(0.25 \% \mathrm{M})$ & $887.5 \pm 26.2$ & $1124.5 \pm 26.0$ & $1382.5 \pm 36.0$ & $1603.5 \pm 43.6$ & $1794.5 \pm 42.7$ & $1992.0 \pm 54.5$ & $2161.5 \pm 63.9$ & $2328.5 \pm 65.7$ & $2442.5 \pm 63.9$ \\
\hline $\mathrm{T}_{4}(0.50 \% \mathrm{~F})$ & $887.0 \pm 33.8$ & $1111.0 \pm 20.1$ & $1328.5 \pm 19.5$ & $1556.5 \pm 22.0$ & $1758.5 \pm 27.7$ & $1998.0 \pm 23.9$ & $2209.0 \pm 23.6$ & $2399.5 \pm 31.7$ & $2522.0 \pm 31.6$ \\
\hline $\mathrm{T}_{5}(0.50 \% \mathrm{M})$ & $885.0 \pm 18.4$ & $1131.5 \pm 15.8$ & $1396.5 \pm 31.3$ & $1567.5 \pm 31.4$ & $1743.5 \pm 32.4$ & $1906.0 \pm 31.0$ & $2056.0 \pm 42.4$ & $2248.0 \pm 67.6$ & $2371.0 \pm 75.0$ \\
\hline $\mathrm{T}_{6}(0.25 \% \mathrm{~F}+0.25 \% \mathrm{M})$ & $887.0 \pm 12.7$ & $1128.0 \pm 19.9$ & $1390.0 \pm 22.4$ & $1624.5 \pm 25.6$ & $1851.0 \pm 33.4$ & $2047.0 \pm 41.4$ & $2206.0 \pm 57.9$ & $2352.5 \pm 61.8$ & $2464.5 \pm 66.5$ \\
\hline $\mathrm{T}_{7}(0.50 \% \mathrm{~F}+0.25 \% \mathrm{M})$ & $888.5 \pm 8.0$ & $1210.5 \pm 27.8$ & $1447.0 \pm 30.5$ & $1696 \pm 41.8$ & $1865.5 \pm 47.2$ & $2029.5 \pm 60.4$ & $2119.5 \pm 63.3$ & $2357.0 \pm 66.0$ & $2487.0 \pm 74.7$ \\
\hline $\mathrm{T}_{8}(0.25 \% \mathrm{~F}+0.50 \% \mathrm{M})$ & $896.0 \pm 11.7$ & $1123.0 \pm 14.0$ & $1388.0 \pm 40.3$ & $1627 \pm 39.3$ & $1847.5 \pm 38.8$ & $1998.5 \pm 43.9$ & $2146.0 \pm 47.6$ & $2343.0 \pm 40.1$ & $2464.5 \pm 48.6$ \\
\hline $\mathrm{T}_{9}(0.50 \% \mathrm{~F}+0.50 \% \mathrm{M})$ & $885.5 \pm 16.3$ & $1148.5 \pm 25.4$ & $1392.5 \pm 37.5$ & $1635 \pm 50.7$ & $1825.0 \pm 50.6$ & $1994.5 \pm 53.6$ & $2138.0 \pm 60.1$ & $2335.5 \pm 62.3$ & $2477.5 \pm 63.2$ \\
\hline Significant & NS & NS & NS & NS & NS & NS & NS & NS & NS \\
\hline
\end{tabular}

NS: Not significant at $\mathbf{P} \geq \mathbf{0 . 0 5}$.

\section{Body weight gain (BWG):}

Results in Table 3 show that different dietary supplementation of fenugreek, marjoram and their combination had insignificant effect on BWG during the experimental period, except at the $9^{\text {th }}, 10^{\text {th }}$ and $12^{\text {th }}$ weeks of age. The group $5(0.50 \% \mathrm{M})$ of rabbits exhibited significantly lowest BWG compared with the other groups from the $9^{\text {th }}$ week of age. During the period from 9 to 10 weeks of age, body weight gains of rabbits were significantly affected by dietary supplementation with $\mathrm{F}+\mathrm{M}$, where group $6(0.25 \% \mathrm{~F}+$ $0.25 \% \mathrm{M})$ gained more weight than the other groups. The group $7 \quad(0.50 \% \mathrm{~F}+0.25 \% \mathrm{M})$ of rabbits less improved BWG compared with the other groups from $12^{\text {th }}$ week of age. Means of body weight gain of NZW rabbits during the whole period were 1656, 1646, 1555, $1635,1486,1577.5,1598.5,1568$ and $1592 \mathrm{~g}$ for groups $1,2,3,4,5,6,7,8$ and 9 , respectively.

Table 3: Effect of dietary supplementation with fenugreek, marjoram, and their combination on weight gain of NZW rabbits from $7^{\text {th }}$ to $14^{\text {th }}$ and 6-14 week of age.

\begin{tabular}{lccccccccc}
\hline \multicolumn{1}{c}{ Age (wk.) } & $\mathbf{7}^{\text {th }}$ & $\mathbf{8}^{\text {th }}$ & $\mathbf{9}^{\text {th }}$ & $\mathbf{1 0}^{\text {th }}$ & $\mathbf{1 1}^{\text {th }}$ & $\mathbf{1 2}^{\text {th }}$ & $\mathbf{1 3}^{\text {th }}$ & $\mathbf{1 4}^{\text {th }}$ & $\mathbf{6 - 1 4}^{\text {wk }}$ \\
& $\bar{X} \pm S E$ & $\bar{X} \pm S E$ & $\bar{X} \pm S E$ & $\bar{X} \pm S E$ & $\bar{X} \pm S E$ & $\bar{X} \pm S E$ & $\bar{X} \pm S E$ & $\bar{X} \pm S E$ & $\bar{X} \pm S E$ \\
Treatments & & & & & & & & \\
\hline $\mathrm{T}_{1}($ Control) & $272 \pm$ & $298 \pm$ & $278 \pm$ & $129 \pm$ & $193 \pm$ & $194 \pm$ & $164 \pm$ & $130 \pm$ & $1656 \pm$ \\
& 29.4 & 28.6 & $18.5^{\mathbf{a}}$ & $10.7^{\mathbf{c}}$ & 25.1 & $26.0^{\mathbf{a b}}$ & 19.0 & 11.3 & 102 \\
$\mathrm{~T}_{2}(0.25 \% \mathrm{~F})$ & $259 \pm$ & $258 \pm$ & $217 \pm$ & $209 \pm$ & $197 \pm$ & $215 \pm$ & $181 \pm$ & $112 \pm$ & $1647 \pm$ \\
& 23.6 & 24.5 & $12.0^{\mathbf{b c}}$ & $11.8^{\mathbf{a b}}$ & 16.7 & $15.0^{\mathbf{a}}$ & 11.0 & 6.06 & 62 \\
$\mathrm{~T}_{3}(0.25 \% \mathrm{M})$ & $237 \pm$ & $258 \pm$ & $221 \pm$ & $191 \pm$ & $198 \pm$ & $170 \pm$ & $167 \pm$ & $114 \pm$ & $1555 \pm$ \\
& 18.7 & 27.5 & $13.9^{\mathbf{b}}$ & $12.8^{\mathbf{a b}}$ & 20.4 & $16.0^{\mathbf{a b}}$ & 24.0 & 8.49 & 67 \\
$\mathrm{~T}_{4}(0.50 \% \mathrm{~F})$ & $224 \pm$ & $218 \pm$ & $228 \pm$ & $202 \pm$ & $240 \pm$ & $211 \pm$ & $191 \pm$ & $123 \pm$ & $1635 \pm$ \\
& 19.7 & 13.0 & $15.0^{\mathbf{a b}}$ & $18.2^{\mathbf{a b}}$ & 14.8 & $17.4^{\mathbf{a}}$ & 16.5 & 6.38 & 46 \\
$\mathrm{~T}_{5}(0.50 \% \mathrm{M})$ & $247 \pm$ & $265 \pm$ & $171 \pm$ & $176 \pm$ & $163 \pm$ & $150 \pm$ & $192 \pm$ & $123 \pm$ & $1486 \pm$ \\
& 27.0 & 24.8 & $20.1^{\mathbf{c}}$ & $26.7^{\mathbf{a b c}}$ & 17.6 & $16.7^{\mathbf{b}}$ & 40.0 & 15.8 & 73 \\
$\mathrm{~T}_{6}(0.25 \% \mathrm{~F}+0.25 \% \mathrm{M})$ & $241 \pm$ & $262 \pm$ & $234.5 \pm$ & $227 \pm$ & $196 \pm$ & $159 \pm$ & $147 \pm$ & $112 \pm$ & $1578 \pm$ \\
& 20.9 & 16.3 & $11.0^{\mathbf{a b}}$ & $15.9^{\mathbf{a}}$ & 23.6 & $24.0^{\mathbf{a b}}$ & 15.4 & 9.04 & 59 \\
$\mathrm{~T}_{7}(0.50 \% \mathrm{~F}+0.25 \% \mathrm{M})$ & $322 \pm$ & $237 \pm$ & $249 \pm$ & $170 \pm$ & $164 \pm$ & $90.0 \pm$ & $238 \pm$ & $130 \pm$ & $1599 \pm$ \\
& 28.2 & 16.1 & $18.3^{\mathbf{a b}}$ & $22.0^{\mathbf{b c}}$ & 22.5 & $18.8^{\mathbf{c}}$ & 14.0 & 10.0 & 71 \\
$\mathrm{~T}_{8}(0.25 \% \mathrm{~F}+0.50 \% \mathrm{M})$ & $227 \pm$ & $265 \pm$ & $239 \pm$ & $221 \pm$ & $151 \pm$ & $148 \pm$ & $197 \pm$ & $122 \pm$ & $1569 \pm$ \\
& 14.0 & 36.0 & $13.3^{\mathbf{a b}}$ & $11.0^{\mathbf{a b}}$ & 18.5 & $10.0^{\mathbf{b}}$ & 18.6 & 11.5 & 49 \\
$\mathrm{~T}_{9}(0.50 \% \mathrm{~F}+0.50 \% \mathrm{M})$ & $263 \pm$ & $244 \pm$ & $243 \pm$ & $190 \pm$ & $170 \pm$ & $144 \pm$ & $198 \pm$ & $142 \pm$ & $1592 \pm$ \\
Significant & 18.3 & 20.7 & $22.0^{\mathbf{a b}}$ & $7.78^{\mathbf{a b}}$ & 18.3 & $16.0^{\mathbf{b}}$ & 21.0 & 8.04 & 64 \\
\hline
\end{tabular}

a-b-c : Means in the same column with different superscripts differ significantly $P \leq 0.05$, NS: Not significant at $P \geq 0.05$, **: Significant at $\mathbf{P} \leq \mathbf{0 . 0 1}$.

\section{Feed intake $(\mathrm{FI})$}

Data of the effect of different levels of fenugreek, marjoram and combined dietary supplementations on weekly feed intake of rabbits are presented in Table 4 . During the $7^{\text {th }}$ week of age, means of feed intake were significantly different among treatments, being 625.5, 596.5, 578, 580, 492, 646, 642.5, 642 and $632 \mathrm{~g} / \mathrm{head}$ for groups $1,2,3,4,5,6,7,8$ and 9, respectively. Rabbits given $0.50 \% \mathrm{M}$ (T5) consumed significantly less feed compared with other groups. The feed consumption of rabbits during the period from $7^{\text {th }}$ to $9^{\text {th }}$ weeks of age was not significantly different among groups. During the $10^{\text {th }}$ week of age, FI was significantly lowest for group $5(0.50 \%$ marjoram $)$. The feed consumption of NZW rabbits during the $11^{\text {th }}, 13^{\text {th }}$ and $14^{\text {th }}$ weeks of age was not significantly different among groups. However, during the $12^{\text {th }}$ week of age, rabbits fed $0.50 \%$ fenugreek plus $0.25 \%$ marjoram consumed significantly less feed compared with other experimental groups. During the whole period (6 to 14 
weeks of age), means of FI of rabbits were not significantly different among experimental groups in agreement with the findings of El-Kloub (2006) who indicated that fenugreek seeds at level of $0.05 \%$ revealed no significant effect on feed intake as compared to the control group. The improvements of feed conversion ratio might be related to the development of rabbit gut morphological changes of gastrointestinal tissues that can be induced by differences in gut-fluid microbial content including their metabolites; the result was in line with finding of Amal et al. (2013) and Mamoun et al. (2014). Gomez et al. (1998) indicated that the improvement in performance characteristics in broilers may be due to antibacterial related to flavonoids in fenugreek that led to maintaining normal intestine microflora by competitive exclusion and antagonism, altering metabolism and increased liver muscle glycogen.

Table 4: Effect of dietary supplementation with fenugreek, marjoram, and their combination on feed intake of NZW rabbits from $6^{\text {th }}$ to $14^{\text {th }}$ and 6-14 week of age.

\begin{tabular}{lccccccccc}
\hline \multicolumn{1}{c}{ Age (wk.) } & $\mathbf{7}^{\text {th }}$ & $\mathbf{8}^{\text {th }}$ & $\mathbf{9}^{\text {th }}$ & $\mathbf{1 0}^{\text {th }}$ & $\mathbf{1 1}^{\text {th }}$ & $\mathbf{1 2}^{\text {th }}$ & $\mathbf{1 3}^{\text {th }}$ & $\mathbf{1 4}^{\text {th }}$ & $\mathbf{6 - 1 4}_{\mathbf{w k}}$ \\
Treatments & $\bar{X} \pm S E$ & $\bar{X} \pm S E$ & $\bar{X} \pm S E$ & $\bar{X} \pm S E$ & $\bar{X} \pm S E$ & $\bar{X} \pm S E$ & $\bar{X} \pm S E$ & $\bar{X} \pm S E$ & $\bar{X} \pm S E$ \\
\hline $\mathrm{T}_{1}($ Control $)$ & $626 \pm$ & $669 \pm$ & $947 \pm$ & $766 \pm$ & $829 \pm$ & $794 \pm$ & $764 \pm$ & $726 \pm$ & $6119 \pm$ \\
& $27^{\mathrm{a}}$ & 15 & $25^{\mathrm{a}}$ & $34^{\mathrm{bc}}$ & 91 & $66^{\mathrm{ab}}$ & 47 & 28 & 268 \\
$\mathrm{~T}_{2}(0.25 \% \mathrm{~F})$ & $597 \pm$ & $668 \pm$ & $870 \pm$ & $818 \pm$ & $933 \pm$ & $905 \pm$ & $813 \pm$ & $725 \pm$ & $6327 \pm$ \\
& $33^{\mathrm{a}}$ & 32 & $14^{\mathrm{ab}}$ & $38^{\mathrm{bc}}$ & 23 & $16^{\mathrm{a}}$ & 21 & 27 & 92 \\
$\mathrm{~T}_{3}(0.25 \% \mathrm{M})$ & $578 \pm$ & $699 \pm$ & $869 \pm$ & $812 \pm$ & $839 \pm$ & $792 \pm$ & $751 \pm$ & $644 \pm$ & $5983 \pm$ \\
& $37^{\mathrm{ab}}$ & 42.8 & $32^{\mathrm{ab}}$ & $26^{\mathrm{bc}}$ & 46 & $60^{\mathrm{ab}}$ & 40 & 29 & 146 \\
$\mathrm{~T}_{4}(0.50 \% \mathrm{~F})$ & $581 \pm$ & $688 \pm$ & $845 \pm$ & $790 \pm$ & $937 \pm$ & $918 \pm$ & $819 \pm$ & $712 \pm$ & $6288 \pm$ \\
& $22^{\mathrm{ab}}$ & 28 & $24^{\mathrm{ab}}$ & $33^{\mathrm{bc}}$ & 10 & $29^{\mathrm{a}}$ & 20 & 28 & 121 \\
$\mathrm{~T}_{5}(0.50 \% \mathrm{M})$ & $492 \pm$ & $715 \pm$ & $823 \pm$ & $719 \pm$ & $887 \pm$ & $832 \pm$ & $710 \pm$ & $688 \pm$ & $5866 \pm$ \\
& $55^{\mathrm{b}}$ & 30.8 & $46^{\mathrm{b}}$ & $77^{\mathrm{c}}$ & 28 & $41^{\mathrm{a}}$ & 83 & 58 & 230 \\
$\mathrm{~T}_{6}(0.25 \% \mathrm{~F}+0.25 \% \mathrm{M})$ & $646 \pm$ & $704 \pm$ & $864 \pm$ & $882 \pm$ & $896 \pm$ & $646 \pm$ & $762 \pm$ & $699 \pm$ & $6098 \pm$ \\
& $20^{\mathrm{a}}$ & 23 & $24^{\mathrm{ab}}$ & $32^{\mathrm{ab}}$ & 67 & $41^{\mathrm{cd}}$ & 46 & 29 & 208 \\
$\mathrm{~T}_{7}(0.50 \% \mathrm{~F}+0.25 \% \mathrm{M})$ & $643 \pm$ & $726 \pm$ & $883 \pm$ & $789 \pm$ & $785 \pm$ & $532 \pm$ & $824 \pm$ & $742 \pm$ & $5922 \pm$ \\
$\mathrm{T}_{8}(0.25 \% \mathrm{~F}+0.50 \% \mathrm{M})$ & $27^{\mathrm{a}}$ & 19 & $53^{\mathrm{ab}}$ & $60^{\mathrm{bc}}$ & $72 \pm$ & $69.5^{\mathrm{d}}$ & 26 & 21 & 177 \\
& $37^{\mathrm{a}}$ & $748 \pm$ & $935 \pm$ & $952 \pm$ & $812 \pm$ & $671 \pm$ & $808 \pm$ & $707 \pm$ & $6275 \pm$ \\
$\mathrm{T}_{9}(0.50 \% \mathrm{~F}+0.50 \% \mathrm{M})$ & $632 \pm$ & $726 \pm$ & $839^{\mathrm{ab}}$ & $24^{\mathrm{a}}$ & 50 & $13^{\mathrm{b}}$ & 14 & 47 & 92 \\
& $17^{\mathrm{a}}$ & 22 & $48^{\mathrm{ab}}$ & $836 \pm$ & $855 \pm$ & $677 \pm$ & $849 \pm$ & $762.5 \pm$ & $6173 \pm$ \\
Significant & $*$ & $\mathrm{NS}$ & $*$ & $* *$ & 67 & $42^{\mathrm{bc}}$ & 15 & 18 & 129 \\
\hline
\end{tabular}

a-b-c-d : Means in the same column with different superscripts differ significantly $(P \leq 0.05)$, NS: Not significant at $P \geq 0.05$, *: Significant at $\mathbf{P} \leq \mathbf{0 . 0 5}$, **: Significant at $\mathbf{P} \leq \mathbf{0 . 0 1}$.

Feed conversion ratio (FCR):

Effects of dietary supplementation of fenugreek and/or marjoram on weekly feed conversion ratio of rabbits are presented in Table 5. During the period from $6^{\text {th }}$ to $8^{\text {th }}$ weeks of age, FCR of rabbits was not significantly affected. However, during the $9^{\text {th }}$ week of age, significantly worst mean of FCR was achieved by the group 5 fed the $0.50 \%$ marjoram as compared with other groups. Also, during the $10^{\text {th }}$ week of age, significantly better mean of FCR was achieved by the group 7 fed $0.50 \%$ fenugreek plus $0.25 \%$ marjoram as compared with other groups. However, during the $11^{\text {th }}$, $13^{\text {th }}$ and $14^{\text {th }}$ weeks of age, there were no significant effects on FCR among all groups, except during the $12^{\text {th }}$ week of age, since there was significantly worst mean of FCR achieved by group 7 fed $0.50 \% \mathrm{~F}$ plus $0.25 \% \mathrm{M}$ as compared with other groups. The FCR of rabbits for the whole experimental period had no significant differences among groups.

Table 5: Effect of dietary supplementation with fenugreek, marjoram, and their combination on feed conversion ratio of NZW rabbits from $7^{\text {th }}$ to $14^{\text {th }}$ and 6-14 week of age.

Age (wk.)

$\begin{array}{lllllllll}7^{\text {th }} & 8^{\text {th }} & 9^{\text {th }} & 10^{\text {th }} & 11^{\text {th }} & 12^{\text {th }} & 13^{\text {th }} & 14^{\text {th }} & 6-14 \text { wk. }\end{array}$

\begin{tabular}{|c|c|c|c|c|c|c|c|c|c|}
\hline ts & $X \pm S E$ & $X \pm S E$ & $X \pm S E$ & $\bar{X} \pm S E$ & $X \pm S E$ & $X \pm S E$ & $X \pm S E$ & $X \pm S E$ & $X \pm S E$ \\
\hline & $2.55 \pm 0.27$ & $46 \pm 0.26$ & $551024^{\mathrm{a}}$ & $6.12 \pm 0.3^{\mathrm{c}}$ & $4.52 \pm 0.32$ & $4.67 \pm 0.51^{\mathrm{a}}$ & & .53 & 3.74 \\
\hline $\mathrm{T}_{2}(0.25 \% \mathrm{~F})$ & $2.51 \pm 0.28$ & $.82 \pm 0.33$ & $4.11 \pm 0.20^{\mathrm{a}}$ & $4.07 \pm 0.36^{\mathbf{a b}}$ & $5.01 \pm 0.35$ & $4.41 \pm 0.32^{\mathrm{a}}$ & $4.68 \pm 0.35$ & $=0.28$ & $3.89 \pm 0.14$ \\
\hline $\mathrm{T}_{3}(0.25 \% \mathrm{M})$ & $2.52 \pm 0.19$ & $.88 \pm 0.21$ & $4.04 \pm 0.24^{\mathrm{a}}$ & $4.39 \pm 0.27^{\mathbf{a b}}$ & $4.71 \pm 0.62$ & $4.92 \pm 0.42^{\mathrm{a}}$ & $5.09 \pm 0.41$ & $5.79 \pm 0.27$ & $3.88 \pm 0.10$ \\
\hline $\mathrm{T}_{4}(0.50 \% \mathrm{~F})$ & $2.75 \pm 0.22$ & $3.24 \pm 0.16$ & $3.83 \pm 0.25^{\mathrm{a}}$ & $4.13 \pm 0.31^{\text {ab }}$ & $4.04 \pm 0.24$ & $4.57 \pm 0.35^{\mathrm{a}}$ & $4.57 \pm 0.41$ & $5.89 \pm 0.23$ & $3.86 \pm 0.0$ \\
\hline $\mathrm{T}_{5}(0.50 \% \mathrm{M})$ & $2.11 \pm 0.27$ & $2.87 \pm 0.25$ & $5.66 \pm 0.58^{b}$ & $4.46 \pm 0.35^{\mathrm{ab}}$ & $6.14 \pm 0.77$ & $5.95 \pm 0.45^{\mathrm{ab}}$ & $4.92 \pm 0.71$ & $5.93 \pm 0.42$ & $3.98 \pm 0.1$ \\
\hline $\mathrm{T}_{6}(0.25 \% \mathrm{~F}+0.25 \mathrm{M})$ & $2.87 \pm 0.26$ & $2.77 \pm 0.18$ & $3.73 \pm 0.12^{\mathrm{a}}$ & $3.99 \pm 0.19^{\mathrm{a}}$ & $4.96 \pm 0.38$ & $4.88 \pm 0.64^{\mathrm{a}}$ & $5.65 \pm 0.49$ & $6.54 \pm 0.46$ & $3.87 \pm 0.05$ \\
\hline $\mathrm{T}_{7}(0.50 \% \mathrm{~F}+.25 \% \mathrm{M})$ & $2.20 \pm 0.27$ & $3.16 \pm 0.17$ & $3.62 \pm 0.15^{\mathrm{a}}$ & $4.93 \pm 0.26^{\mathbf{b}}$ & $5.27 \pm 0.43$ & $6.92 \pm 0.58^{\mathbf{b}}$ & $3.57 \pm 0.24$ & $5.89 \pm 0.31$ & $3.73 \pm 0.09$ \\
\hline $\mathrm{T}_{8}(0.25 \% \mathrm{~F}+.50 \% \mathrm{M})$ & $2.90 \pm 0.20$ & $3.08 \pm 0.24$ & $3.99 \pm 0.16^{\mathrm{a}}$ & $4.41 \pm 0.20^{\mathbf{a b}}$ & $5.69 \pm 0.30$ & $4.84 \pm 0.48^{\mathrm{a}}$ & $4.52 \pm 0.53$ & $6.09 \pm 0.43$ & $4.02 \pm 0.09$ \\
\hline $\mathrm{T}_{9}(0.50 \% \mathrm{~F}+0.50 \% \mathrm{M})$ & $2.49 \pm 0.15$ & $3.09 \pm 0.17$ & $3.63 \pm 0.24^{\mathrm{a}}$ & $4.45 \pm 0.16^{\text {ab }}$ & $5.35 \pm 0.34$ & $5.14 \pm 0.46^{\mathrm{a}}$ & $4.73 \pm 0.49$ & $5.52 \pm 0.33$ & $3.91 \pm 0.10$ \\
\hline Significant & NS & NS & $* *$ & $* *$ & NS & $* *$ & NS & NS & NS \\
\hline
\end{tabular}

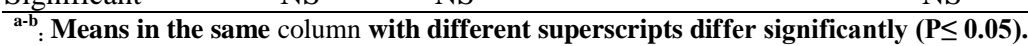


Carcass traits:

Results given in Table 6 show the effect of fenugreek and/or marjoram on carcass traits of NZW rabbits at the $14^{\text {th }}$ week of age. The results showed that dietary supplementation of fenugreek, marjoram and their combination had no significant effect on relative weights of carcass yield, liver or heart. Results of carcass weight were in harmony with final live body weight. This result was in line with finding of Zeweil et al. (2015) indicate that diets containing $0.6 \%$ fenugreek seeds had no significant effect on carcass weight percent and organs relative weights as compared with the control group

Table 6: Effect of dietary supplementation with fenugreek, marjoram, and their combination on carcass traits (\% of live body weight at slaughter) of NWZ rabbits.

\begin{tabular}{lccccc}
\hline \multicolumn{1}{c}{ Age (wk.) } & $\begin{array}{c}\text { LBW } \\
(\mathbf{g})\end{array}$ & carcass wt. (\%) & $\begin{array}{c}\text { Heart wt. } \\
(\boldsymbol{\%})\end{array}$ & $\begin{array}{c}\text { Liver wt. } \\
(\boldsymbol{\%})\end{array}$ & $\begin{array}{c}\text { Dressed carcass wt. } \\
(\boldsymbol{\%})\end{array}$ \\
& $\bar{X} \pm S E$ & $\bar{X} \pm S E$ & $\bar{X} \pm S E$ & $\bar{X} \pm S E$ & $\bar{X} \pm S E$ \\
Treatments & $2519.3 \pm 51.2$ & $59.78 \pm 2.75$ & $0.32 \pm 0.05$ & $2.72 \pm 0.12$ & $62.81 \pm 2.86$ \\
& $2521.5 \pm 26.3$ & $60.03 \pm 0.29$ & $0.34 \pm 0.02$ & $2.85 \pm 0.17$ & $63.21 \pm 0.30$ \\
$\mathrm{~T}_{1}($ Control) & $2501.5 \pm 33.6$ & $59.26 \pm 0.45$ & $0.33 \pm 0.02$ & $3.05 \pm 0.26$ & $62.64 \pm 0.41$ \\
$\mathrm{~T}_{2}(0.25 \% \mathrm{~F})$ & $2506.8 \pm 32.7$ & $58.77 \pm 0.82$ & $0.35 \pm 0.02$ & $3.23 \pm 0.24$ & $62.36 \pm 0.70$ \\
$\mathrm{~T}_{3}(0.25 \% \mathrm{M})$ & $2609.8 \pm 71.4$ & $59.19 \pm 0.77$ & $0.34 \pm 0.02$ & $3.16 \pm 0.18$ & $62.71 \pm 0.80$ \\
$\mathrm{~T}_{4}(0.50 \% \mathrm{~F})$ & $2499.5 \pm 34.3$ & $59.87 \pm 1.07$ & $0.33 \pm 0.02$ & $2.71 \pm 0.23$ & $62.91 \pm 1.21$ \\
$\mathrm{~T}_{5}(0.50 \% \mathrm{M})$ & $2569.0 \pm 73.5$ & $59.12 \pm 0.43$ & $0.29 \pm 0.02$ & $2.81 \pm 0.28$ & $62.22 \pm 0.36$ \\
$\mathrm{~T}_{6}(0.25 \% \mathrm{~F}+0.25 \% \mathrm{M})$ & $58.28 \pm 1.05$ & $0.31 \pm 0.03$ & $2.99 \pm 0.31$ & $61.57 \pm 0.88$ \\
$\mathrm{~T}_{7}(0.50 \% \mathrm{~F}+0.25 \% \mathrm{M})$ & $2473.0 \pm 19.6$ & $58.77 \pm 0.72$ & $0.34 \pm 0.01$ & $3.66 \pm 0.27$ & $62.78 \pm 0.53$ \\
$\mathrm{~T}_{8}(0.25 \% \mathrm{~F}+0.50 \% \mathrm{M})$ & $\mathrm{NS}$ & $\mathrm{NS}$ & $\mathrm{NS}$ & $\mathrm{NS}$ \\
$\mathrm{T}_{9}(0.50 \% \mathrm{~F}+0.50 \% \mathrm{M})$ & $2559.8 \pm 62.6$ & $\mathrm{NS}$ & & &
\end{tabular}

NS: Not significant at $\mathbf{P} \geq \mathbf{0 . 0 5}$.

\section{CONCLUSION}

The consumption of fenugreek and marjoram had positive effects on rabbit's performance and carcass traits of growing NZW rabbits.

\section{REFERENCES}

Abd El-Latif .A. M., M .Y. Ibrahim and A. S. Mahmoud (2012). Antidiabetic effects of fenugreek (Trigonella foenum-graecum) seeds in the domestic rabbit (Oryctolagus cuniculus). Research Journal of Medicinal Plant, 6 (6): 449455.

Amal, O. A., M. A. Mukhtar, K. A. Mohamed and H. Ahlam (2013). Use of half bar essential oil (HBO) as a natural growth promoter in broiler nutrition. International Journal of Poultry Science, 12: 15-18.

Botsoglou N.A., Florou-Paneri P., Christaki E., Giannenas I., Spais A.B. (2004). Performance of rabbits and oxidative stability of muscle tissues as affected by dietary supplementation with oregano essential oil. Arch. Anim. Nutr., 58: 209218.

Cervato, G., M. Carabelli, S. Gervasio, A. Cittera, R. Cazzola and B. Cestaro (2000). Antioxidant properties of oregano (Origanum vulgare) leaf extracts. J. Food Biochem., 24: 453-465.

Daouk, R.K., S.M. Dagher and E.J. Sattout (1995). Antifungal activity of the essential oil of origanum Syriacum L. J. Food Prot., 58: 11471149.
De Blas, J. C. and Mateos, G. G. (1998). Feed formulation In: The Nutrition of the Rabbit. (De Blas and J, Wiseman Eds). Wallingford, CABI Publ., UK. Chapter 13, 241-254.

De Koning, W.H., D.H. Biao, W.X. Fu and R. Yi (1993). Chinese herbs in animal nutrition. London, England: Nottingham University Press, 31-74.

Dorman, H.J.D. and S.G. Deans (2000). Antimicrobial agents from plants: Antibacterial activity of plant volatile oils. J. Appl. Microbiol., 88: 308-316.

Duncan, D.B. (1955). Multiple range and multiple F tests. Biometrics, 11: 1-42.

El-Kloub, M. (2006). Effect of using commercial and natural growth promoters on the performance of commercial laying hens. Egyptian Poultry Science, 26: 941-965.

Gomez, M. P., B. Geetha and G. Asker (1998). Antidiabetic effects of fenugreek extracts (Trigonellafoenum-graecum L.) on domestic animals with special reference to carbohydrate metabolism. Journal of Ecotoxicology and Environmental Monitoring, 8: 103-108.

Gupta, K., K. K. Thakral, S. K. Arora and M. 1. Chowdhary (1996). Structural carbohydrate and mineral seeds. Indian Coca Arecenut and Species J, 20: 120 .

Hernandez, F., J. Madrid, V. Garcia, J. Orengo and M. D. Megias (2004). Influence of two plant extracts on broilers performance, digestibility, and digestive organ size. Poult. Sci., 83: 169 - 174. 
Ibrahim, S.A.M., El-Ghamry, A.A., El-Mallah, G.M. (2000). Effect of some medicinal plants of Lablatae family as feed additives on growth and metabolic changes of rabbits. Egypt. J. Rabbit Sci., 10 (1): 105-120.

Kor, Z. M.and G. B. Zadeh (2013). Fenugreek (Trigonellafoenum-graecum L.) As a Valuable Medicinal Plant.International Journal of Advanced Biological and Biomedical Research, 1 (Issue 8): 922-931.

Mamoun, T., M. A. Mukhtar and M. H. Tabidi (2014). Effect of fenugeeek seed powder on the performance, carcass characteristics and some blood serum attributes. Adv. Res. Agri. Vet. Sci., 1 (1): 6-11.

Qureshi, S., M.T. Banday, S. Adil, I. Shakeel and Z.H. Munshi (2015). Effect of dandelion leaves and fenugreek seeds with or without enzyme addition on performance and blood biochemistry of broiler chicken and evaluation of their in vitro antibacterial activity. Ind. J. Anim. Sci., 85: 1248-1254.

Rayes, N., D. Sechofer and P. Neuhaus (2009). Prebiotics probiotics, synbiotics in surgery--are they only trendy truly effective or even dangerous? Langenbecks Arch. Surg; 394 (3): 547-55.

Robu, T. and C. Milic ă (2004). Plante medicinale autohtone . Ed. Institutul European, Ia şi.
SAS (1996). Statistical Analysis System. SAS User's Guide: Statistics SAS institute Inc., Cary, NC, USA.

Seleem, T.S.T. (2008). Rabbit productivity and reproductivity as affected by fenugreek in diets. The $1^{\text {st }}$ Egyptin Conference on Rabbits Sciences, 142-153.

Srinivasan, K. (2006). Fenugreek (Trigonellafoenum graecum) a Review of Health Beneficial Physiological Effects. Food Reviews International, 22: 203-224.

Untea, A., R. Criste, T. Panaite and I. Costache (2011). Effect of the dietary oregano (Origanum vulgare) on $\mathrm{Cu}$ and $\mathrm{Zn}$ balance in weaned piglets. Journal of Trace Elements in Medicine and Biology, 25S: S35-S40.

Yatoo M.A., M.V.Sc. Scholar, Sharma R.K., Khan Nazam, M.V.Sc. Scholar, Rastogi Ankur, Pathak A.K. (2012). Effect of fenugreek and black cumin seeds as feed additives on blood biochemical profile and performance of broilers. Indian Journal of Animal Nutrition. 29 (Issue: 2): $174-178$.

Zeweil, H. S., S. M. Zahran, M. H. Abd El-Rahman, Yasmin El-Gindy and J. Embark (2015). Effect of fenugreek and anise seeds as natural growth promoter on the performance, carcass, blood constituents and antioxidant status of growing rabbits. Egypt. Poult. Sci., 35 (IV): 909-921.

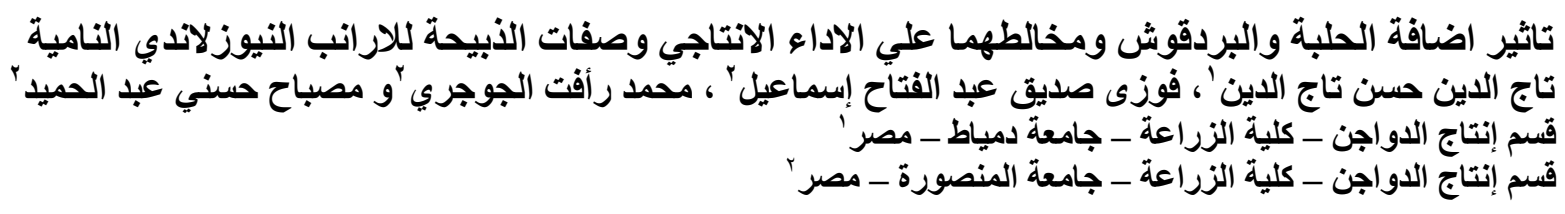

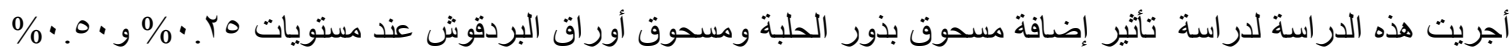

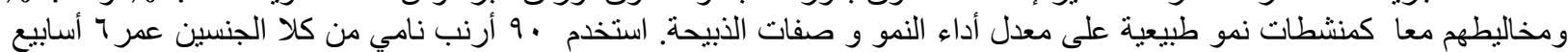

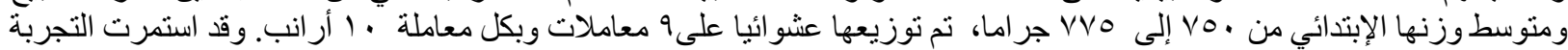

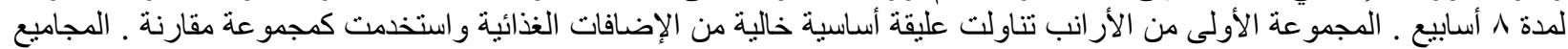

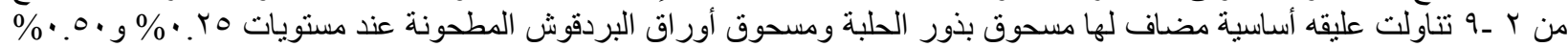

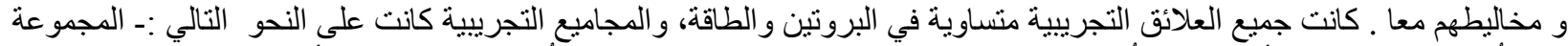

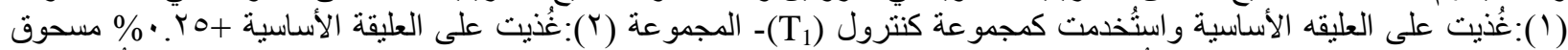

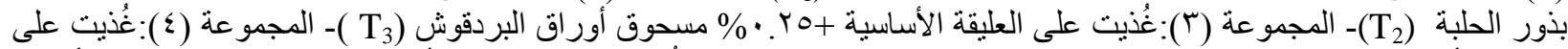

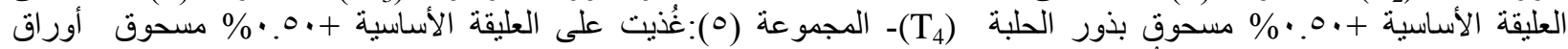

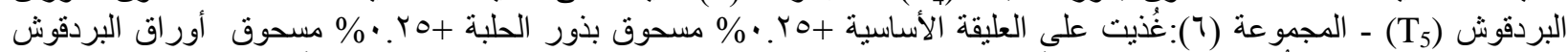

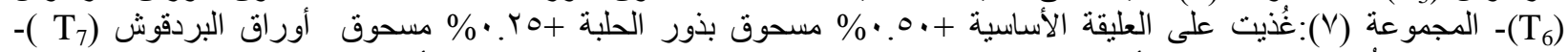

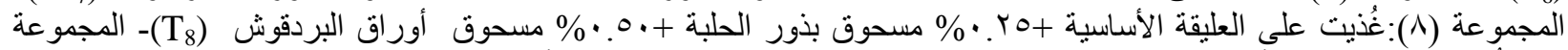

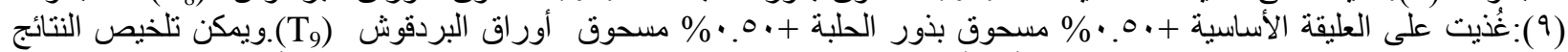

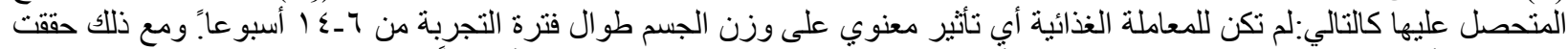

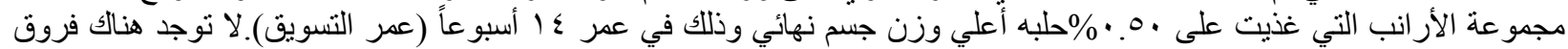

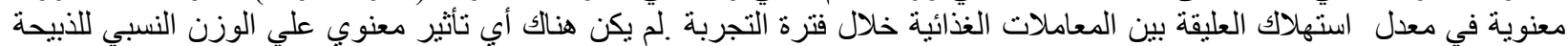

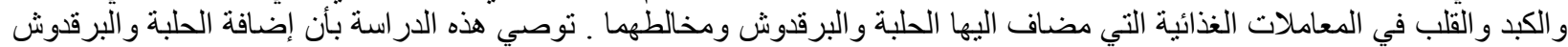

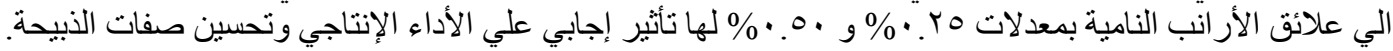

